This item was submitted to Loughborough's Research Repository by the author.

Items in Figshare are protected by copyright, with all rights reserved, unless otherwise indicated.

\title{
Non-suicidal self-injury and suicidality in trans people: a systematic review of the literature
}

PLEASE CITE THE PUBLISHED VERSION

http://dx.doi.org/10.3109/09540261.2015.1073143

PUBLISHER

(c) Taylor \& Francis

\section{VERSION}

AM (Accepted Manuscript)

\section{PUBLISHER STATEMENT}

This work is made available according to the conditions of the Creative Commons Attribution-NonCommercialNoDerivatives 4.0 International (CC BY-NC-ND 4.0) licence. Full details of this licence are available at: https://creativecommons.org/licenses/by-nc-nd/4.0/

\section{LICENCE}

CC BY-NC-ND 4.0

\section{REPOSITORY RECORD}

Marshall, E., L. Claes, Walter P. Bouman, Gemma L. Witcomb, and Jon Arcelus. 2019. "Non-suicidal Selfinjury and Suicidality in Trans People: A Systematic Review of the Literature". figshare.

https://hdl.handle.net/2134/18985. 
Non-Suicidal Self-Injury and Suicidality in Trans People: A Systematic Review of the Literature

Ellen Marshall ${ }^{1,2}$, Laurence Claes ${ }^{3}$, Walter Pierre Bouman ${ }^{1}$, Gemma L.Witcomb ${ }^{1,2}$, and Jon Arcelus ${ }^{1,4}$

${ }^{1}$ Nottingham Centre for Gender Dysphoria, Nottingham, United Kingdom

${ }^{2}$ School of Sport, Exercise, and Health Sciences, Loughborough University, United Kingdom

${ }^{3}$ Faculty of Psychology and Educational Sciences, KU Leuven, Leuven, Belgium

${ }^{4}$ Division of Psychiatry and Applied Psychology, Faculty of Medicine \& Health Sciences, University of Nottingham, Nottingham, United Kingdom

Correspondence: Prof. Jon Arcelus, Nottingham Centre for Gender Dysphoria, 3 Oxford Street, Nottingham, NG1 5BH. United Kingdom. Tel: +44 1158760160 e-mail: J.Arcelus@lboro.ac.uk 


\begin{abstract}
Literature has described high levels of mental health problems among trans people, such as depression, resulting in increased levels of non-suicidal self-injury (NSSI) behaviour and suicidality (suicidal thoughts, suicide attempts and suicide rates). With the aim of systematically reviewing the available literature in this field, this study identifies thirty-one papers that explore the rates of NSSI and suicidality in trans people. From reviewing the literature, it was revealed that trans people have a higher prevalence of NSSI and suicidality compared to the cisgender (non-trans) population. There appear to be some gender differences within these rates, with trans men at a greater risk for NSSI behaviour. Prevalence rates differ depending on the different stages of transition, but they are still overall greater than the cisgender population. The study concludes that trans individuals are at a greater risk of NSSI behaviour and suicidality than the cisgender population, and discusses risk factors and the need to develop effective preventative interventions.
\end{abstract}

Keywords: Gender Dysphoria, Trans, Transsexual, Suicide, Non-suicidal Self Injury, Review 


\section{Introduction}

As defined by the new edition of the American Psychiatric Association's classification system (DSM5; APA, 2013) people with Gender Dysphoria present with a discomfort or distress that is caused by a discrepancy between a person's gender identity and that person's sex assigned at birth (and the associated gender role and/or primary and secondary sex characteristic). The World Health Organisation in its current International Classification of Diseases $10^{\text {th }}$ edition (ICD-10) (WHO, 1992) defines Transsexualism as the desire to live and be accepted as a member of the opposite sex, usually accompanied by the wish to make the person's body as congruent as possible with the preferred sex through hormone treatment and surgery (WHO, 1992). It is likely that the new edition of the ICD, which is expected to be published in 2017 will replace transsexualism with a diagnosis of Gender Incongruence (Drescher et al., 2012). This diagnosis will also include people who do not necessarily want to transition from one binary gender to other. The terminology in this field has changed over the years and the terms 'transgender' and 'trans' have been used in the literature as umbrella terms to cover a wide variety of atypical gender experiences and expressions which may lead to a change of social gender role, but does not necessarily include cross-sex hormone treatment or surgical intervention (Coleman et al., 2012; Wylie et al., 2014).

Recent studies have reported an overall meta-analytical prevalence for transsexualism of 4.6 in 100,000 individuals; 6.8 for trans women and 2.6 for trans men, which is primarily based on studies looking at individuals attending clinical services (Arcelus et al., 2015. Although, due to the low prevalence rates, the number of studies in the field of trans is small, there have been a number of studies that have described the strong association between mental health problems, particularly depression, and trans people (Clements-Nolle, Marx, Guzman, \& Katz, 2001; Couch et al., 2007; Hepp, Kraemer, Schnyder, Miller, \& Delsignore, 2005; Nemoto et al., 2006; Nuttbrock et al., 2010; Operario \& Nemoto, 2005). This is not surprising as the discomfort and distress that trans people experience may lead to low mood, self-injury and even suicide (Dhejne et al., 2011). 
Non-suicidal self-injury (NSSI) refers to the direct and intentional injury of one's own body tissue without suicidal intent, such as cutting, burning, and hitting oneself, and has been found to function as a way to regulate emotions and self-punishment (Claes \& Vandereycken, 2007). Studies investigating this behaviour have interchangeably used different terms to define it, including self-harm, cutting, self-injury as well as NSSI. Investigating rates as well as risk factors of NSSI and suicide in trans people is important as it may help to understand vulnerability factors and may inform the development of preventative interventions to minimise the risk in this vulnerable population.

Three previous studies have reviewed the literature investigating the rates of mental health problems in Lesbian, Gay, Bisexual and Trans (LGBT) populations. As part of these reviews the authors have described some studies in the field of NSSI and suicidality, within the LGBT population (Haas et al., 2011; Pandya, 2014; Skerrett, Kolves \& De Leo, 2015). These have mainly found that there is an elevated risk for mental health problems among LGBT people, including self-harm. These reviews are limited by the lack of the systematic methodology used and the fact that they do not focus exclusively on the trans population. It is because of this that the aim of the present study was to conduct a systematic review of the literature examining prevalent rates of NSSI and suicidality within the trans population.

\section{Methodology}

\section{Eligibility Criteria}

Articles selected included all methodological designed studies that explore prevalence rates of NSSI and suicide within the trans population. Studies were selected only if trans participants, both selfidentified and diagnosed by professionals, were included. LGBT studies were accepted only if information for trans participants from the LGB group was provided separately. Additionally, studies 
were only eligible if they looked specifically at NSSI prevalent rates or suicidality (suicidal thoughts, suicide attempts and suicide rates). Articles that were researching mental health and psychopathology in general, with no description of NSSI and suicide rates were not included. Only studies in English were selected. For inclusion and exclusion criteria see Table 1.

\section{Insert table 1 around here}

\section{Information Sources and Search}

The systematic review adheres to the guidelines detailed in the PRISMA Statement (Moher, Liberati, Tetzlaff \& Altman, 2009). An electronic literature search was conducted between January 1966 and April 2015 using Medline/Pubmed, PsycINFO and Embase. Four full-text collections were also searched: Science Direct, Ingenta Select, Ovid Full text, and Wiley-Blackwell Interscience. Additionally, reference sections of identified articles and Google Scholar were examined for further relevant publications. The search used the following keywords: for terms referring to Trans people (Transsexualism, transgender, Gender Dysphoria, Gender Identity Disorder, Trans*), for NSSI, (selfharm, self-injury, Non-Suicidal Self Injury, NSSI) and for Suicide (suicide, suicidality, suicidal ideas, suicide attempts and mortality). Every term used for Trans people was combined using the "OR” and the "AND” operate with the every term used for NSSI and Suicidality. Articles of interest were those that included the transgender population and had empirical data relating to the prevalence rate of either NSSI or suicidality within this population. Articles describing the potential vulnerability factors associated with NSSI and suicide for the transgender population were also collected and reviewed in order to help the discussion of the paper. A second researcher (GW) completed an independent literature search using the same method described to further increase the validity of the search. 


\section{Study Selection}

As per PRISMA guidelines, studies were screened for eligibility in three stages: title, abstract and full text. In the first phase of screening by titles $(n=223)$, duplicates were removed and the remaining titles ( $\mathrm{n}=123)$ were screened for eligibility for the present study. This was then followed by screening the abstracts of the remaining studies $(n=73)$, which was followed by full text screening which yielded 31 studies. This final sample of 31 studies was discussed and agreed with the second researcher (GW) and were therefore included in the systematic review. Throughout the screening process the eligibility criteria were used to assess the appropriateness of the studies. The main data that was extracted from the studies was: suicidal thoughts, suicide attempts, suicidal rates and NSSI prevalence rates and potential vulnerability factors (see Figure 1).

\section{Insert Figure 1 around here}

Data extraction was performed independently using a standardised table with the following categories: title, author, date of publication, country of publication, population characteristics, sample size, main findings and prevalence rate (if applicable). The studies will be presented divided into two categories:

1) NSSI and trans people

2) Suicidality (including suicidal thoughts, suicide attempts and suicide rates) and trans people.

\section{Results}

\section{Study Characteristics}

The sample sizes of the thirty-one studies included in this review ranged from 24 to 6456 . The first study published in this area was in 1975 by Wålinder and Thuwe. The 31 studies include a mix of 
youth, adults and older participants who were at different stages of transition, with seven studies using post-hormone treatment and post-surgical trans people as their sample. Out of the thirty-one studies, twenty-five (80.6\%) described a trans population, with six (19.35\%) studies researching the LGBT population and distinguishing the trans participants as a separate sub-group within this group. The studies reviewed were conducted in different countries worldwide, including UK $(n=5)$, USA $(n=$ 12), the Netherlands ( $n=2)$ and Australia $(n=2)$. The most common methodology used was self-report questionnaires although a range of sampling techniques and study designs were used. Seventeen (54.9\%) studies looked at prevalence rates, five (16.1\%) looked at the vulnerability factors associated with an elevated risk and nine (29\%) looked at both the prevalence rates and vulnerability factors.

\section{NSSI and Trans people}

Five of the thirty-one (16.1\%) studies investigated the relationship between NSSI and trans people. The first study investigating prevalence rates of NSSI in trans people is an American study by Walls et al. (2010). Studying cutting behaviour within LGBT youths, the authors found that out of the thirteen self-identified trans participants, six reported engaging in self-cutting behaviour during the past year. In a more recent study, Claes et al. (2014) found a high prevalence rate of NSSI within their trans sample, with $38 \%$ of the sample having a life-time history of NSSI. They also found that prevalence was higher in trans men (57.7\%) than trans women (26.2\%). Additionally the authors described that NSSI behaviour was associated with psychopathology and interpersonal problems as well as low levels of social support. Only one type of NSSI behaviour (cutting) was assessed in this study and although evidence suggests this to be the most common form of NSSI (Claes \& Vandereycken, 2007), there may be other NSSI behaviours that affect the trans population. The authors selected a population of trans people attending clinical services, with a diagnosis of transsexualism as per the ICD-10 (WHO, 1992) and who were at the early stage of the assessment process. Therefore the findings reported relate to NSSI behaviour pre-assessment and before the commencement of treatment and possibly transition. As there is strong evidence of improved psychological and social functioning following social gender role 
transition (Cohen et al., 1997; Johansson et al., 2010; Murad et al., 2010) the high rates of NSSI behaviour in this study may be a reflection of the specific population selected. A study using similar methodology but selecting a population of trans people attending clinical services and at different stages of the transitional and treatment process found that trans participants had a significantly higher rate of NSSI compared to a control sample (Davey et al., 2015). The authors report that $19 \%$ of the trans sample (half of the one reported by Claes et al, 2014) had engaged in some form of NSSI at some point within their lifetime. They also reported that trans men were more at risk of NSSI than trans women.

Studies examining levels of NSSI in young people attending the only Gender Identity Development Service in the UK for children and adolescents found a strong association between a diagnosis of gender dysphoria (as defined by the authors) and self-harm (defined as non-suicidal selfharm by the authors), with $24 \%$ of the patients reporting previously engaging in self-harm behaviour (Holt, Skagerburg \& Dunsford, 2014). They explain that the high prevalence of self-harm may be associated with the difficulties whilst going through social transition. The authors also found that selfharm was more common in trans males than trans females. In a similar study of adolescent transgender clients, Skagerberg, Parkinson and Carmichael (2013) found similar results as above, with 39\% of their client sample reporting self-harm (particularly young people over the age of 12 years). Interestingly, the authors reported that although thoughts of self-harm were more common in trans females compared to trans males, actual self-harm was more common in trans males. The authors further reported that the most common type of NSSI was self-cutting. Although the study has a good sample size $(n=218)$, it is limited by the methodology as it gathers the information using a non-standardised method of data collection from patient's files, which may underestimate actual self-harming rates. Additionally, the data was collected over an 8 month period which adds some limitations to the study. In spite of this, the message of all the above studies is clearly indicative of higher levels of NSSI behaviour among trans people, adults and youngsters, particularly trans males. 


\section{Insert table 2 around here}

\section{Suicidality in Trans people}

\section{$\underline{\text { Suicidal thoughts and attempts in Trans people }}$}

There are twenty-six studies investigating the association between suicidality (suicidal thoughts, suicide attempts and suicide rates) and trans people. Eighteen (69.2\%) studies describe suicidal thoughts and intentions and eight (30.8\%) report rates of suicide in this population.

Five studies (19.2\%) used LGBT participants as their sample and distinguished between the subgroups so directly researching the trans participants in their analysis. The first of these studies by Mustanski and Liu (2012) investigated suicidal attempts in an LGBT group. The authors use psychiatric interviews within a longitudinal design that included a 1-year follow-up. They reported that $52.4 \%$ of the trans sample $(n=21)$ had a history of lifetime suicide attempt or attempts, $19 \%$ had a suicide attempt in the past year and 9.5\% had attempted suicide between the original interview and the 1 year follow-up. These findings were nearly double to the LGB sample that had a lifetime suicide attempt history of $29.3 \%$.

Two years later, an American study by Mereish, O’Cleirigh, and Bradford (2014) recruited a large group of LGBT participants from a community health centre $(n=1457)$. They also distinguished between the subgroups in their analysis. The authors reported very high prevalence rates for both lifetime history of suicide ideation (68.7\%) and suicide attempt (31.2\%). Both studies (Mustanski \& Liu, 2012; Mereish, O’Cleirigh \& Bradford., 2014) are limited by the small numbers of trans participants ( $n=21$ and $n=11$ respectively) compared to their overall sample size as well as by the self-identifying nature of the trans population studied. 
The earliest study exclusively in trans people confirmed previous studies in the LGBT group and also showed that trans individuals reported significantly more suicidal ideation and attempt than cisgender people (Mathy, 2003). This study found that the prevalence rate for a lifetime history of suicide ideation in the trans sample was $37 \%$, compared to $24.2 \%$ for cisgender females (non-trans natal females) and 13\% for cisgender males (non-trans natal males). The prevalence rate for suicide attempt in the trans sample was $23.3 \%$, compared to $11.4 \%$ for cisgender female and $5 \%$ for cisgender male. Despite the small sample size of just 73 participants, the findings do show an elevated rate of suicidality among the trans population.

In 2006, Clements-Nolle, Marx and Katz reported that out of their 515 self-identified trans participants, 32\% reported attempting suicide at some point in their lifetime. This is significantly much greater than the national average of the USA (4.6\%), where the study took place. Furthermore, the authors found that predictors of suicide for their sample included younger age ( $<25$ years), depression, substance abuse history, and past history of sexual abuse. The authors also explained that gender-based discrimination and victimisation may help to explain the high suicide risk within the trans population. Despite the large sample that this study used, the researchers used a cross-sectional study design so they are unable to make conclusions about causality. However, this does not affect the prevalence rate for suicide attempts reported.

Four years later, Maguen and Shipherd (2010) reported a prevalence rate of suicide attempt of $18 \%$ in their trans population, which is nearly half of the previously reported rates. This could be explained by selection procedure of the specific population: participants at a conference for trans people. As per studies in NSSI, they also found that trans men had a higher prevalence rate (41\%) than trans women (20\%). The authors found a positive association between being natal female, psychiatric hospitalisation, experienced trans-related violence and suicidal attempt. Due to the convenience 
sampling method used for recruitment, the findings may underestimate the rates of suicidal attempt in the trans population.

In the same year, Mustanski, Garafalo and Emerson (2010) similarly found an increased suicide risk for the trans population. In their study of LGBT youth $(n=246)$ that distinguished between the different sub-groups, the authors found that $45 \%$ of their trans sample had a lifetime history of suicide attempts. Ten percent of their sample had attempted suicide and the same number reported suicide ideation within the past year. Despite the high prevalence rates for suicidality within the trans population, the authors commented that the suicide behaviours were similar to those among representative youth samples in the same geographical area, although no control group was used in this study.

Through analysis of the descriptive data from the National Transgender Discrimination Survey (NTDS), Haas, Rodgers and Herman (2014) reported that the prevalence of suicide attempts among respondents was $41 \%$, which vastly exceeds the $4.6 \%$ of the overall U.S. population. It is also higher than the $10-20 \%$ of the LGB population who report ever attempting suicide, showing the importance of distinguishing between the subgroups of LGBT in research. When researching the factors that contribute to vulnerability of suicidality in the trans population, the authors also found that mental health problems and experiences of harassment, discrimination, violence and rejection may increase the risk in this population. The study found that suicide attempts were highest amongst those who were younger (aged 18-24), suggesting age or factors related to age (such as impulsivity) to be a risk factor for suicidality. The NTDS is the largest survey of transgender and gender non-conforming adults to date which provides validity and reliability to the findings. However, the survey was looking at discrimination of the trans population as a whole and did not specifically research suicidality. As a result, the NTDS questionnaire included only a single item about suicidal behaviour that asked 'Have you ever attempted suicide?' with closed answer responses of yes/no. Due to the lack of follow-up 
questions and/or suicidal ideation questions, the analysis is limited to just suicide attempts and insightful information may have been missed.

A study using a matched control design by Resiner, White, Bradford and Mimiaga (2014) found similar results. The authors compared physical and mental health differences between trans and cisgender adults. Using their matched-pair subsample, which controlled for age, ethnicity, educational attainment and income, in a large trans population $(n=155)$, they found trans people to be more likely to endorse a lifetime suicide attempt and ideation compared to cisgender people. As per previous studies (Grossman \& D’Augelli, 2007; Spack et al., 2012), they also identify age as an important vulnerability factor for suicidality as trans youth was found to have a twofold to threefold increased risk of suicidal ideation, suicide attempt and NSSI.

Finally, in the most recent study in the field so far, lifetime prevalence rates for suicidal ideation of $81 \%$ have been found in a sample of 273 trans male participants, and more than a third reported an attempted suicide. The participants also reported high levels of self-harm, showing once again the relationship between gender dysphoria and self-injuring behaviour (Jones et al., 2015).

In spite of the methodological limitations of many studies, all the studies investigating suicidality in the trans population have found considerable higher rates of self-injury in the trans population compared to cisgender people, primarily among young trans men.

\section{Insert table 3 around here}

\section{$\underline{\text { Suicide rates in Trans people post-treatment }}$}

There are few studies looking at suicide rates within the trans population, particularly focusing on post-treatment. One of those studies by Van Kesteren, Asscheman, Megens and Gooren (1997) 
found that although total mortality rate after hormone treatment was not higher than in the general population, the number of cases of suicide was higher compared with the expected mortality rates for suicide, particularly among the trans female sample. The number of suicide for trans males was similar to the one expected in the cisgender population. These findings were confirmed in an impressive follow up study of post-treatment trans people (Dhejne et al., 2011). The authors found that the overall mortality rate for sex-reassigned persons was higher than for controls of the same birth sex, particularly death from suicide. They also reported that sex-reassigned persons had an increased risk for suicide attempts, suggesting that the suicide risk for the trans population may not be reduced after treatment and transition. These results confirm those from a Dutch study of transgender population on long-term sex hormones. In this study Asscheman et al. (2011) found that mortality by suicide was increased by six-fold among trans female sample compared to the cisgender population. There were no significant differences of mortality rates in the trans males, compared to the cisgender population, possibly due to the small number of transmen compared to trans female.

\section{Discussion}

This systematic literature review has found a strong association between gender dysphoria, NSSI and suicidality (suicidal thoughts, suicide attempts and suicide rates). In terms of NSSI in trans people, all of the research studies within this area found a high prevalence of NSSI among trans people, in particular trans men, when compared to cisgender people. It could be hypothesised that the biological influences attached to being born phenotypically female may play a part in the way people deregulate their emotions, as research has already identified NSSI to be more common among cisgender females than cisgender males (Claes \& Vandereycken, 2007). Despite the gender differences, both trans men and trans women have been found to present with a higher prevalence of NSSI compared to the general cisgender population showing the strong association between the two, possibly mediated by mental health problems, such as depression. 
Unfortunately, this is not only the case for NSSI, but also for suicidality. Studies investigating prevalence rates of suicidality among trans people showed an increase of suicide ideation, suicide attempts and suicide rates, even after transition and sex reassignment surgery when compared to the cisgender population (De Cuypere et al., 2005; Eldh, Berg \& Gustafsson, 1997; Johansson, Sorenson \& Hertoft, 1982; Walinder \& Thuwe, 1975), suggesting that although NSSI rates may decrease from pretransition to transition (Claes et al., 2014; Davies et al., 2015) suicidality and more worryingly, suicide rates are still significantly greater than in the cisgender population (Dhejne et al., 2011, Asscheman et al., 2011). Although some of these findings require replication, it may indicate that vulnerability to mental health problems and suicidality may increase with age in the trans population, possibly linked to a lack of social support, loneliness, victimisation and discrimination, as these factors have been found to be associated with poor quality of life in trans people (Davey et al., 2014, 2015).

The association between NSSI and suicidality among trans people may indicate the need to explore this issue further in order to understand it better. Risk of NSSI among the trans population has been found to be associated with lack of perceived social support (Davey et al., 2014), interpersonal problems (Claes et al., 2015), and has also been linked to trans men and young age. Interventions aimed at increasing support and improving interpersonal skills may be useful in preventing NSSI behaviour. For example, currently little formal support is provided to help families and children of trans parents to understand, cope with, and hopefully support their loved ones' gender identity and transition. For some trans people, the desire to transition can result in the complete loss of contact with family, or in contrast, the desire to protect children who may be struggling to understand can lead a trans person to halt any exploration of their gender identity, which may lead to depression. Therefore, targeting interventions to help those people that are close to the trans person, rather than the trans person themselves, may increase the amount of social support that is able to be given to the trans person, and as a result, improve their mental health. Other interventions may help trans people develop 
new coping skills. For example, exercise as medicine is now being promoted in many areas of mental health (Stanton et al., 2015). This is because not only does exercise release endorphins that are a feel good hormone and increases in physical capacity can lead to increased feelings of self-esteem and selfefficacy (Dang, 2010), but participation in group sport or exercise can promote positive feelings of ingroup membership, friendship, and social support that have been shown to increase quality of life (Penedo \& Dahn, 2005) and can act as a buffer against other negative feelings and experiences that may otherwise lead to NSSI behaviour. Sport participation has been shown to protect against hopelessness and suicidal ideation in adolescents (Taliaferro, 2008). In addition, the rates of suicidality among trans people at follow-up post-surgery may indicate a need for a better preparation of trans people when discharged from clinical services, acknowledging the difficulties they may encounter, and aiming at developing coping skills through seeking and developing the support of significant others. This may include greater efforts to address the lack of knowledge shared by many employers, schools/colleges and communities in order to increase their ability to be able to support the trans person as they develop in their new role without stigma.

\section{Limitations}

As with all systematic reviews the content of this paper is limited by the quality of studies available. Despite the consistent findings of an association between gender dysphoria and NSSI and suicide risk, there are methodological problems particularly related to the number of people included, although more recent studies have investigated considerably larger numbers of trans individuals. As most of the studies that research gender dysphoria and NSSI and suicide are from developed countries (primarily the Netherlands, UK and USA) their findings may not be generalizable to other countries and cultures where NSSI is not as common. Additionally, as the majority of the studies in this area are cross-sectional clear conclusions regarding predictive factors are difficult to make. Future research should use longitudinal methodology to investigate risk factors at different stages of transition. 
It is important to add that as the majority of the studies investigate NSSI and suicidality among trans individuals attending clinical services, their findings cannot be generalized to trans people who have never accessed such services. Some studies have tried to avoid this limitation by recruiting attendees at transgender conferences; however, this introduces a different bias. Future research will need to use a broader and more varied selection of participants in order to represent the whole trans population. Such participants could include self-identified trans individuals, those on the treatment pathway, fully transitioned individuals and those who are currently just questioning their gender identity. Finally, it is possible that the lack of social support reported by trans people may in fact be a product of another mental health issues, for example depression. It would be valuable to investigate whether those people close to a trans person do in fact report difficulties in offering support, or whether support if offered is not recognised or accepted by the trans person. If support is there, then interventions aimed at increasing support within the family or family of choice is not going to be effective. Rather, the underlying negative cognitive biases that lead to a lack of support being perceived needs to be targeted.

Despite the methodological limitations these studies have, they have all found similar results, suggesting that there is an association between being trans, NSSI and suicidality. The findings from the research tend to suggest that most of the difficulties associated with gender dysphoria and NSSI and suicidality are associated with the experience of victimisation, and lack of social acceptance, which could be mediated by depression. As in the general cisgender population, the reviewed studies have also identified that NSSI and suicidality are driven by intrapersonal and interpersonal factors, suggesting the importance of preventative interventions aiming at reducing those factors. As research have demonstrated that identity issues increase the risk for NSSI and suicidality, increasing education in order to change people's perceptions about trans people and by doing so decrease victimisation and isolation, may not be enough to help trans people. Additionally, it will require the need for access to 
psychological and/or physical interventions aiming to reduce gender dysphoria as well as, in a broader sense, robust legislation to promote equality and diversity within society.

Declaration of interest: The authors report no conflict of interest. The authors alone are responsible for the content and writing of the paper 


\section{REFERENCES}

American Psychiatric Association (2013). Diagnostic and Statistical Manual of Mental Disorders-5

(DSM-5). Washington, DC: American Psychiatric Association.

Arcelus, J., Bouman, W.P., Van De Noortgate, W., Claes, L., Witcomb, G.L., \& Fernandez-Aranda, F. Systematic review and meta-analysis of prevalence studies in transsexualism. European Psychiatry. Online first: DOI: http://dx.doi.org/10.1016/j.eurpsy.2015.04.005

Asscheman, H., Giltay, E. J., Megens, J. A., van Trotsenburg, M. A., \& Gooren, L. J. (2011). A longterm follow-up study of mortality in transsexuals receiving treatment with cross-sex hormones. European Journal of Endocrinology, 164, 635-642.

Birkett, M., Newcomb, M. E., \& Mustanski, B. (2015). Does it get better? A longitudinal analysis of psychological distress and victimization in lesbian, gay, bisexual, transgender, and questioning youth. Journal of Adolescent Health, 56, 280-285.

Claes, L., \& Vandereycken, W. (2007). Self-injurious behavior: differential diagnosis and functional differentiation. Comprehensive Psychiatry, 48, 137-144.

Claes, L., Bouman, W. P., Witcomb, G., Thurston, M., Fernandez-Aranda, F. and Arcelus, J. (2015). Non-Suicidal Self-Injury in Trans People: Associations with Psychological Symptoms, Victimization, Interpersonal Functioning, and Perceived Social Support. Journal of Sexual Medicine, 12, 168-179.

Clements-Nolle, K., Marx, R., \& Katz, M. (2006). Attempted suicide among transgender persons: The influence of gender-based discrimination and victimization. Journal of Homosexuality, 51, 53-69.

Clements-Nolle, K., Marx, R., Guzman, R., \& Katz, M. (2001). HIV prevalence, risk behaviors, health care use, and mental health status of transgender persons: Implications for public health intervention. American Journal of Public Health, 91, 915-21. 
Cohen, L., de Ruiter, C., Ringelberg, H., \& Cohen-Kettenis, P. T. (1997). Psychological functioning of adolescent transsexuals: Personality and psychopathology. Journal of Clinical Psychology, 53, 187196.

Coleman, E., Bockting, W., Botzer, M., Cohen-Kettenis, P., DeCuypere, G., Feldman, J., ... Zucker, K. (2012). Standards of Care for the Health of Transsexual, Transgender, and Gender-Nonconforming People, Version 7. International Journal of Transgenderism, 13, 165-232.

Couch, M., Pitts, M., Mulcare, H., Croy, S., Mitchell, A. and Patel, S. (2007). TranZnation: A Report on the Health and Wellbeing of Transgender People in Australia and New Zealand. Melbourne: Australian Research Centre in Sex, Health and Society.

Dang, M. T. (2010). Walking Away the Blues: Exercise for Depression in Older Adults. Nursing, 40, 33-36.

Davey, A., Arcelus, J., Meyer, C., and Bouman, W.P. (2015). Self injury among trans individuals in transition and matched controls: Prevalence and Associated factors. Health and Social Care in the Community (in press). DOI: 10.1111/hsc.12239

Davey, A., Bouman, W. P., Arcelus, J., \& Meyer, C. (2014). Social Support and Psychological WellBeing in Gender Dysphoria: A Comparison of Patients with Matched Controls. Journal of Sexual Medicine, 11, 2976-2985.

De Cuypere, G., T’Sjoen, G., Beerten, R., Selvaggi, G., De Sutter, P., Hoebeke, P., ... Rubens, R. (2005). Sexual and physical health after sex reassignment surgery. Archives of Sexual Behavior, 34, 679-690.

Dhejne, C., Lichtenstein, P., Boman, M., Johansson, A. L. V., Langstrom, N., \& Landen, M. (2011). Longterm follow-up of transsexual persons undergoing sex reassignment surgery: Cohort study in Sweden. PloS One, 6, 1-8. 
Drescher, J., Cohen-Kettenis, P., \& Winter, S. (2012). Minding the body: situating gender identity diagnoses in the ICD-11. International Review of Psychiatry, 24, 568-77. DOI:10.3109/09540261.2012.741575

Eldh J, Berg, J. E. A., \& Gustafsson, M. (1997). Long term follow up after sex reassignment surgery. Scandinavian Journal of Plastic and Reconstructive Surgery and Hand Surgery, 31, 39-45.

Grossman, A. H., \& D'Augelli, A. R. (2007). Transgender Youth and Life-Threatening Behaviors. Suicide and Life-Threatening Behavior, 37, 527-537.

Haas, A. P., Eliason, M., Mays, V. M., Mathy, R. M., Cochran, S. D., D'Augelli, A., ... Clayton, P.J. (2011). Suicide and suicide risk in lesbian, gay, bisexual, and transgender populations: review and recommendations. Journal of Homosexuality, 58, 10-51.

Hepp, U., Kraemer, B., Schnyder, U., Miller, N., \& Delsignore, A. (2005). Psychiatric comorbidity in gender identity disorder. Journal of Psychosomatic Research, 58, 259-261.

Herman, J., Haas, A., \& Rodgers, P. (2014). Suicide attempts among transgender and gender nonconforming adults. Los Angeles: The Williams Institute, UCLA.

Holt, V., Skagerberg. E., \& Dunsford, M. (2015). Young people with features of gender dysphoria: Demographics and associated difficulties. Clinical Child Psychology and Psychiatry (in press). DOI:10.1177/1359104514558431.

Johansson, A., Sundbom, E., Höjerback, T., \& Bodlund, O. (2010). A five-year follow-up study of Swedish adults with gender identity disorder. Archives of Sexual Behavior, 39, 1429-1437.

Jones, T., de Bolger, A. D. P., Dune, T., Lykins, A., \& Hawkes, G. (2015). Female-to-Male (FtM) Transgender People’s Experiences in Australia: A National Study. Germany: Springer.

Maguen, S., \& Shipherd, J. C. (2010). Suicide risk among transgender individuals. Psychology \& Sexuality, 1, 34-43. 
Mathy, R. M. (2003). Transgender identity and suicidality in a nonclinical sample: Sexual orientation, psychiatric history, and compulsive behaviors. Journal of Psychology \& Human Sexuality, 14, 47-65.

Mereish, E. H., O’Cleirigh, C., \& Bradford, J. B. (2014). Interrelationships between LGBT-based victimization, suicide, and substance use problems in a diverse sample of sexual and gender minorities. Psychology, Health \& Medicine, 19, 1-13.

Moher, D., Liberati, A., Tetzlaff, J., \& Altman, D. G. (2009). Preferred reporting items for systematic reviews and meta-analyses: the PRISMA statement. Annals of Internal Medicine, 151, 264-269.

Moody, C., \& Smith, N. G. (2013). Suicide protective factors among trans adults. Archives of Sexual Behavior, 42, 739-752.

Murad, M. H., Elamin, M. B., Garcia, M. Z., Mullan, R. J., Murad, A., Erwin, P. J., \& Montori, V. M. (2010). Hormonal therapy and sex reassignment: a systematic review and meta-analysis of quality of life and psychosocial outcomes. Clinical Endocrinology, 72, 214-231.

Mustanski, B. S., Garofalo, R., \& Emerson, E. M. (2010). Mental health disorders, psychological distress, and suicidality in a diverse sample of lesbian, gay, bisexual, and transgender youths. American Journal of Public Health, 100, 2426-2432.

Mustanski, B., \& Liu, R. T. (2013). A longitudinal study of predictors of suicide attempts among lesbian, gay, bisexual, and transgender youth. Archives of Sexual Behavior, 42, 437-448.

Nuttbrock, L., Hwahng, S., Bockting, W., Rosenblum, A., Mason, M., Macri, M., \& Becker, J. (2010). Psychiatric impact of gender-related abuse across the life course of male-to-female transgender persons. Journal of Sex Research, 47, 12-23.

Operario, D., \& Nemoto, T. (2005). Sexual risk behavior and substance use among a sample of Asian Pacific Islander transgendered women. AIDS Education and Prevention, 17, 430-443. 
Penedo, F.J. \& Dahn, J.R. (2005). Exercise and Well-being: A Review of Mental and Physical Health Benefits Associated with Physical Activity. Current Opinion in Psychiatry, 18, 189-193.

Pandya, A. (2014). Mental health as an advocacy priority in the lesbian, gay, bisexual, and transgender communities. Journal of Psychiatric Practice, 20, 225-227.

Reisner, S. L., White, J. M., Bradford, J. B., \& Mimiaga, M. J. (2014). Transgender health disparities: comparing full cohort and nested matched-pair study designs in a community health center. LGBT Health, 1, 177-184.

Skagerberg, E., Parkinson, R., \& Carmichael, P. (2013). Self-harming thoughts and behaviors in a group of children and adolescents with gender dysphoria. International Journal of Transgenderism, 14, 86-92.

Skerrett, D. M., Kõlves, K., \& De Leo, D. (2015). Are LGBT populations at a higher risk for suicidal behaviors in Australia? Research findings and implications. Journal of Homosexuality (in press).

Sørensen, T., \& Hertoft, P. (1982). Male and female transsexualism: The Danish experience with 37 patients. Archives of Sexual Behavior, 11, 133-155.

Spack, N. P., Edwards-Leeper, L., Feldman, H. A., Leibowitz, S., Mandel, F., Diamond, D. A., \& Vance, S. R. (2012). Children and adolescents with gender identity disorder referred to a pediatric medical center. Pediatrics, 129, 418-425.

Spittal, M. J., Fedyszyn, I., Middleton, A., Bassilios, B., Gunn, J., Woodward, A., \& Pirkis, J. (2015). Frequent callers to crisis helplines: Who are they and why do they call? Australian and New Zealand Journal of Psychiatry, 49, 54-64.

Stanton, R., Rosenbaum, S., Kalucy, M., Reaburn, P., \& Happell, B. (2015). A call to action: exercise as treatment for patients with mental illness. Australian Journal of Primary Health, 21, 120-125. 
Taliaferro, L.A., Rienzo, B.A., Miller, M.D., Pigg, R.M., \& Dodd, V.J. (2008). High School Youth and Suicide Risk: Exploring Protection Afforded Through Physical Activity and Sport Participation. Journal of School Health, 78, 545-553.

Van Kesteren, P. J., Asscheman, H., Megens, J. A., \& Gooren, L. J. (1997). Mortality and morbidity in transsexual subjects treated with cross-sex hormones. Clinical Endocrinology, 47, 337-343.

Wålinder, J., \& Thuwe, I. (1975). A social-psychiatric follow-up study of 24 sex-reassigned transsexuals. Göteborg, Sweden: Scandinavian University Books.

Walls, N. E., Laser, J., Nickels, S. J., \& Wisneski, H. (2010). Correlates of cutting behavior among sexual minority youths and young adults. Social Work Research, 34, 213-226.

World Health Organisation (1992). International Classification of Diseases 10 (ICD-10). Geneva: World Health Organisation.

Wylie, K., Barrett, J., Besser, M., Bouman, W. P., Bridgman, M., Clayton, A., ... Rathbone, M. (2014). Good Practice Guidelines for the Assessment and Treatment of Adults with Gender Dysphoria. Sexual Relationship Therapy, 29, 154-214. DOI:10.1080/14681994.2014.883353 
Table 1: Criteria for searches on NSSI, Suicide, and trans people.

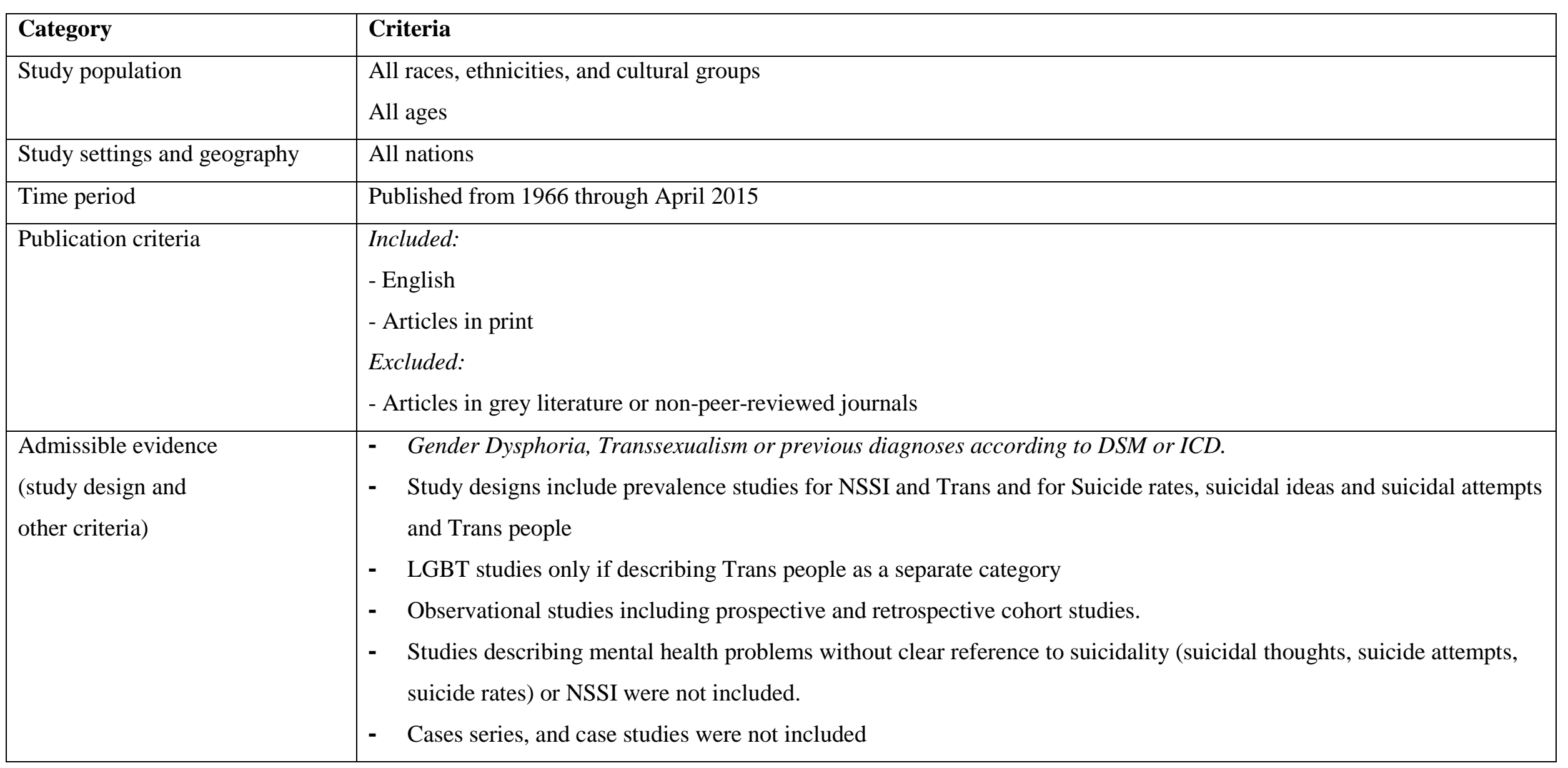


Table 2: Studies investigating rates of Non Suicidal Self Injuries (NSSSI) in Trans people ( $\mathrm{n}=5$ ).

\begin{tabular}{|c|c|c|c|c|c|}
\hline Author & Date & Country & Population / Sample & Sample size (n) & Results \\
\hline Walls et al. & 2010 & USA & LGBT youths & $\begin{array}{l}\text { LGBT }(n)=265 \\
\text { Trans }(n)=13 \\
(4.9 \% \text { of sample })\end{array}$ & $\begin{array}{l}6 \text { out of } 13 \text { trans participants reported } \\
\text { engaging in NSSI behaviour during the } \\
\text { past year. }\end{array}$ \\
\hline $\begin{array}{l}\text { Skagerberg, } \\
\text { Parkinson \& } \\
\text { Carmichael }\end{array}$ & 2013 & UK & $\begin{array}{l}\text { Trans children and adolescents referred to } \\
\text { gender identity clinic. Researched NSSI } \\
\text { at assessment stage } \\
\text { Mean age }=13.56\end{array}$ & $\begin{array}{l}125 \\
\mathrm{TF}=69(54.8 \%) \\
\mathrm{TM}=56(45.2 \%)\end{array}$ & $\begin{array}{l}\text { NSSI in Transmen }>\text { NSSI in transwomen } \\
\text { Most common type of NSSI = cutting } \\
\text { Thoughts of self-harm in } \\
\text { transwomen }>\text { Thoughts of self-harm in } \\
\text { transmen } \\
\text { NSSI and suicide thoughts more common } \\
\text { above age of } 12\end{array}$ \\
\hline Claes et al. & 2014 & UK & $\begin{array}{l}\text { People over the age of } 18 \mathrm{y} \text {, with a } \\
\text { diagnosis of Transsexualism attending a } \\
\text { national gender clinic. Trans people were } \\
\text { at assessment stage. Trans Adults were } \\
\text { compared with an aged matched } \\
\text { cisgender control sample. }\end{array}$ & $\begin{array}{l}155 \\
\mathrm{TF}=103(66.5 \%) \\
\mathrm{TM}=52(33.5 \%)\end{array}$ & $\begin{array}{l}\text { NSSI }=36.8 \% \text { of trans } \\
\text { NSSI in trans men }>\text { NSSI in trans } \\
\text { women and cisgender people } \\
\text { NSSI associated to psychological + } \\
\text { interpersonal problems, less social } \\
\text { support } \\
\text { Most common type of NSSI = cutting }\end{array}$ \\
\hline $\begin{array}{l}\text { Holt, } \\
\text { Skagerburg \& } \\
\text { Dunsford }\end{array}$ & 2014 & UK & $\begin{array}{l}\text { Children and adolescents with gender } \\
\text { features of gender dysphoria. All trans } \\
\text { people were undergoing treatment for } \\
\text { gender dysphoria } \\
\text { Mean age = } 14\end{array}$ & $\begin{array}{l}218 \\
\mathrm{TF}=81(37.2 \%) \\
\mathrm{TM}=137(62.8 \%)\end{array}$ & $\begin{array}{l}\text { Most common type of NSSI= self- } \\
\text { harming } \\
\text { NSSI in transmen> NSSI in transwomen }\end{array}$ \\
\hline Davey et al. & 2015 & UK & $\begin{array}{l}\text { People over the age of } 18 \mathrm{y} \text {, with a } \\
\text { diagnosis of Transsexualism attending a } \\
\text { national gender clinic. Trans people were } \\
\text { at different stages of transition. Trans } \\
\text { Adults were compared with an aged } \\
\text { matched cisgender control sample. }\end{array}$ & $\begin{array}{l}97 \\
\mathrm{TF}=60(61.9 \%) \\
\mathrm{TM}=37(38.1 \%)\end{array}$ & $\begin{array}{l}\text { NSSI }=19 \% \text { of trans } \\
\text { Trans participants }>\text { NSSI than cisgender } \\
\text { people } \\
\text { NSSI in Transmen }>\text { NSSI in trans women } \\
\text { and cisgender people. } \\
\text { Most common type of NSSI = cutting }\end{array}$ \\
\hline
\end{tabular}

TF: Trans female; TM: Trans male; NSSI: Non Suicidal Self-Injury 
Table 3: Studies investigating rates of Suicidality in Trans people $(\mathrm{n}=26)$.

\begin{tabular}{|c|c|c|c|c|c|}
\hline $\begin{array}{l}\text { Walinder \& } \\
\text { Thuwe }\end{array}$ & 1975 & Sweden & Transgender - post surgery & 24 & $\begin{array}{l}\text { Reported } 1 \text { suicide in follow up } \\
\text { Suicide prevalence rate }=4.2 \%\end{array}$ \\
\hline $\begin{array}{l}\text { Sorenson \& } \\
\text { Hertoft }\end{array}$ & 1982 & Denmark & $\begin{array}{l}\text { Transgender - post surgery } \\
\text { Followed for an average of } 6 \text { years }\end{array}$ & $\begin{array}{l}37 \\
\mathrm{TF}=29(78.4 \%) \\
\mathrm{TM}=8(21.6 \%)\end{array}$ & $\begin{array}{l}\text { Reports death by suicide in } 3(\mathrm{TF}) \text { out of } \\
29 \\
\text { Suicide prevalence rate }=10.3 \% \text { for } \mathrm{TF}\end{array}$ \\
\hline $\begin{array}{l}\text { Eldh, Berg \& } \\
\text { Gustafsson }\end{array}$ & 1997 & Sweden & $\begin{array}{l}\text { Transgender - post surgery } \\
\text { Long-term follow-up }\end{array}$ & 136 & $\begin{array}{l}\text { Reports } 3 \text { suicides } \\
\text { Suicide prevalence rate }=2.2 \%\end{array}$ \\
\hline $\begin{array}{l}\text { Van Kesteren, } \\
\text { Asscheman, } \\
\text { Megens \& } \\
\text { Gooren }\end{array}$ & 1997 & Holland & $\begin{array}{l}\text { Transgender - treated with hormones } \\
\text { Compared with standardised morality } \\
\text { calculated from the general Dutch } \\
\text { population (age- and gender-adjusted) }\end{array}$ & $\begin{array}{l}1109 \\
\mathrm{TF}=816(73.6 \%) \\
\mathrm{TM}=293(26.4 \%)\end{array}$ & $\begin{array}{l}\text { Suicides in TF sample: } 13(\mathrm{SMRs}=9.29) \\
\text { Suicide prevalence rate }=1.6 \% \text { for trans } \\
\text { Suicides for TM similar to SMRs }\end{array}$ \\
\hline $\begin{array}{l}\text { De Cuypere et } \\
\text { al. }\end{array}$ & 2005 & Belgium & $\begin{array}{l}\text { Transgender - post surgery. Underwent } \\
\text { surgery with the Ghent Gender team } \\
\text { between } 1986 \text { and } 2001\end{array}$ & $\begin{array}{l}55 \\
\mathrm{TF}=32(58.2 \%) \\
\mathrm{TM}=23(41.8 \%)\end{array}$ & $\begin{array}{l}\text { Not aware of any suicides or suicide } \\
\text { attempts in their sample } \\
\text { Suicide prevalence rate }=0 \%\end{array}$ \\
\hline
\end{tabular}




\begin{tabular}{|c|c|c|c|c|c|}
\hline $\begin{array}{l}\text { Clements- } \\
\text { Nolle, Marx \& } \\
\text { Katz }\end{array}$ & 2006 & USA & Transgender (self-identified) & $\begin{array}{l}515 \\
\mathrm{TF}=392(76 \%) \\
\mathrm{TM}=123(23 \%)\end{array}$ & $\begin{array}{l}\text { Attempted suicide rate }=32 \% \\
\text { Predictors = younger age }(<25) \text {, } \\
\text { depression, substance abuse history, } \\
\text { forced sex history, gender-based } \\
\text { discrimination, gender-based } \\
\text { victimisation }\end{array}$ \\
\hline $\begin{array}{l}\text { De Cuypere et } \\
\text { al. }\end{array}$ & 2006 & Belgium & Transgender - post-surgery & $\begin{array}{l}62 \\
\mathrm{TF}=35(56.5 \%) \\
\mathrm{TM}=27(43.5 \%)\end{array}$ & $\begin{array}{l}\text { Transgender people are at an elevated } \\
\text { risk for suicide attempt during gender } \\
\text { transition, while rates of suicide attempts } \\
\text { decrease after gender transition. } \\
\text { Suicide attempt rate }=5.1 \% \text { of trans } \\
\text { population after transition }\end{array}$ \\
\hline Whittle et al. & 2007 & UK & Transgender & 873 & $\begin{array}{l}\text { Transgender people are at an elevated } \\
\text { risk for suicide attempt during gender } \\
\text { transition, while rates of suicide attempts } \\
\text { decrease after gender transition. }\end{array}$ \\
\hline $\begin{array}{l}\text { Grossman \& } \\
\text { D'Augelli }\end{array}$ & 2007 & USA & Transgender youth - aged 15-21 & $\begin{array}{l}55 \\
\mathrm{TF}=31(56.4 \%) \\
\mathrm{TM}=24(43.6 \%)\end{array}$ & $\begin{array}{l}\text { Suicide ideation prevalence }=45 \% \\
\text { Suicide attempt prevalence }=26 \% \\
\text { Nearly half of the sample reported having } \\
\text { thought about taking their lives and a } \\
\text { quarter reported suicide attempts }\end{array}$ \\
\hline $\begin{array}{l}\text { Johansson, } \\
\text { Sundbom, } \\
\text { Hojerback \& } \\
\text { Bodlund } \\
\end{array}$ & 2008 & Sweden & $\begin{array}{l}\text { Transgender - through their surgery } \\
\text { journey }\end{array}$ & $\begin{array}{l}60 \\
\mathrm{TF}=39(65 \%) \\
\mathrm{TM}=21(35 \%)\end{array}$ & $\begin{array}{l}\text { Reported no suicides or suicide attempts } \\
\text { in the } 60 \text { transsexual patients } \\
\text { Suicide prevalence rate }=0 \%\end{array}$ \\
\hline $\begin{array}{l}\text { Maguen \& } \\
\text { Shipherd }\end{array}$ & 2010 & USA & $\begin{array}{l}\text { Transgender (self-identified) recruited at } \\
\text { a transgender conference } \\
\text { Aged 18-75 }\end{array}$ & $\begin{array}{l}153 \\
\mathrm{TF}=125(81.7 \%) \\
\mathrm{TM}=28(18.3 \%)\end{array}$ & $\begin{array}{l}\text { Suicide attempt prevalence rate }=18 \% \\
\text { Trans men }(41 \%)>\text { trans women }(20 \%) \\
\text { Factors associated with suicide history }= \\
\text { assigned female at birth, psychiatric } \\
\text { hospitalisation and experienced trans- } \\
\text { related violence }\end{array}$ \\
\hline
\end{tabular}




\begin{tabular}{|c|c|c|c|c|c|}
\hline $\begin{array}{l}\text { Mustanski, } \\
\text { Garafalo \& } \\
\text { Emerson }\end{array}$ & 2010 & USA & $\begin{array}{l}\text { LGBT youths (self-identified) } \\
\text { Aged 16-20. Mean age = } 18 . \\
\text { Recruited via various methods, including } \\
\text { convenience and snowball sampling }\end{array}$ & $\begin{array}{l}\text { LGBT }=246 \\
\text { Trans }=20(8.1 \%) \\
\text { TF }=12(60 \%) \\
\text { TM }=8(40 \%)\end{array}$ & $\begin{array}{l}\text { Lifetime suicide rate }=45 \% \text { of trans pop. } \\
\text { Suicide attempts in last } 12 \text { months }=10 \% \\
\text { of trans pop. } \\
\text { Suicide behaviours were similar to those } \\
\text { among representative youth samples in } \\
\text { the same geographical area }\end{array}$ \\
\hline Dhejne et al. & 2011 & Sweden & $\begin{array}{l}\text { Transgender - post surgery } \\
\text { A population matched-cohort study = } \\
\text { Matched by birth year and birth sex or } \\
\text { reassigned (final) sex, respectively }\end{array}$ & $\begin{array}{l}324 \\
\mathrm{TF}=191(59 \%) \\
\mathrm{TM}=133(41 \%)\end{array}$ & $\begin{array}{l}\text { Suicide deaths and attempts in trans pop. } \\
>\text { Heterosexual pop. } \\
\text { Suicide deaths }=2.7 \% \text { in trans pop. } \\
\text { Suicide deaths }=0.1 \% \text { in matched } \\
\text { controls } \\
\text { Suicide attempts }=7.9 \% \text { in trans pop. } \\
\text { Suicide attempts }=1 \% \text { in matched } \\
\text { controls }\end{array}$ \\
\hline $\begin{array}{l}\text { Asscheman et } \\
\text { al. }\end{array}$ & 2011 & Holland & $\begin{array}{l}\text { Trans patients receiving long-term cross- } \\
\text { sex hormones }\end{array}$ & $\begin{array}{l}\text { 1331: } \\
\text { TF = } 966(72.6 \%) \\
\text { TM = } 365(27.4 \%)\end{array}$ & $\begin{array}{l}\text { Total morality for TF trans pop. }=51 \% \\
\text { higher than general population. Mainly } \\
\text { due to suicide and other health problems. } \\
\text { Total morality for TM pop. = } \\
\text { not significantly different to general } \\
\text { population. }\end{array}$ \\
\hline $\begin{array}{l}\text { Mustanski \& } \\
\text { Liu }\end{array}$ & 2012 & USA & $\begin{array}{l}\text { LGBT Youth - } \\
\text { Age requirement: } 16-20 \text { Venue and } \\
\text { snowball sampling was used and the } \\
\text { participants self-identified their sexual } \\
\text { orientation and gender }\end{array}$ & $\begin{array}{l}237 \\
\text { Trans n=21 (8.9\%) }\end{array}$ & $\begin{array}{l}\text { Lifetime suicide rate }=52.4 \% \text { of trans } \\
\text { pop. } \\
\text { Lifetime suicide rate }=29.3 \% \text { of LGB } \\
\text { pop. } \\
\text { Suicide rate of trans pop > LGB pop. } \\
\text { Attempted suicide in past year = } 19 \% \text { of } \\
\text { trans pop. } \\
\text { Attempted suicide in } 12 \text {-month follow-up } \\
=9.5 \% \text { of trans pop. } \\
\text { LGBT specific factors = early age of } \\
\text { same-sex attraction and victimisation }\end{array}$ \\
\hline Spack et al. & 2012 & USA & Paediatric Medical Centre patients - & 97 & Found $9.3 \%$ of patients presented with a \\
\hline
\end{tabular}




\begin{tabular}{|c|c|c|c|c|c|}
\hline & & & $\begin{array}{l}\text { Diagnosed with Gender Identity Disorder } \\
(<21 \text { years })\end{array}$ & $\begin{array}{l}\mathrm{TF}=43(44.3 \%) \\
\mathrm{TM}=54(55.7 \%)\end{array}$ & suicide attempt \\
\hline $\begin{array}{l}\text { Moody \& } \\
\text { Smith }\end{array}$ & 2013 & Canada & $\begin{array}{l}\text { Trans adults (self-identified) } \\
\text { Aged 18-75. Mean age }=36.75 \\
\text { Recruited through online advertising }\end{array}$ & $\begin{array}{l}133 \\
\mathrm{TF}=59(44.4 \%) \\
\mathrm{TM}=56(42.1 \%) \\
\text { Intersex }=3(2.3 \%) \\
\text { Other }=11(8.3 \%) \\
\end{array}$ & $\begin{array}{l}\text { Found social support and optimism } \\
\text { significantly, negatively predicted } 33 \% \text { of } \\
\text { the variance in participant's suicidal } \\
\text { behaviour }\end{array}$ \\
\hline $\begin{array}{l}\text { McCann, } \\
\text { Sharek, } \\
\text { Higgins, } \\
\text { Sheerin \& } \\
\text { Glacken } \\
\end{array}$ & 2013 & Ireland & LGBT Irish older population ( $>55$ years) & $\begin{array}{l}144 \\
\text { Trans = } 10 \text { (6.9\%) }\end{array}$ & $\begin{array}{l}\text { Elevated risk of mental health problems } \\
\text { within the LGBT population which may } \\
\text { lead to suicide and NSSI }\end{array}$ \\
\hline $\begin{array}{l}\text { Haas, Rodgers } \\
\text { \& Herman }\end{array}$ & 2014 & USA & $\begin{array}{l}\text { Respondents to the National Transgender } \\
\text { Discrimination Survey (NTDS) - } \\
\text { Transgender and gender non-conforming } \\
\text { adults }\end{array}$ & $\begin{array}{l}6456 \\
\mathrm{TF}=3870(59.9 \%) \\
\mathrm{TM}=2566 \\
(39.7 \%)\end{array}$ & $\begin{array}{l}\text { Prevalence of suicide attempts }=41 \% \\
\text { Prevalence of suicide attempts highest } \\
\text { among those who are younger (18-24: } \\
45 \%) \text { multiracial (54\%) and American } \\
\text { Indian or Alaska Native (56\%) } \\
\text { Main factors for increased vulnerability: } \\
\text { Mental health factors, experiences of } \\
\text { discrimination, violence and rejection }\end{array}$ \\
\hline $\begin{array}{l}\text { Mereish, } \\
\text { O’Cleirigh \& } \\
\text { Bradford }\end{array}$ & 2014 & USA & $\begin{array}{l}\text { LGBT patients from a community health } \\
\text { centre }\end{array}$ & $\begin{array}{l}\text { LGBT = } 1457 \\
\text { Trans }=16(1.1 \%)\end{array}$ & $\begin{array}{l}\text { Suicide ideation prevalence rate }=68.8 \% \\
\text { Suicide attempt prevalence rate }=31.3 \%\end{array}$ \\
\hline $\begin{array}{l}\text { Reisner, White, } \\
\text { Bradford \& } \\
\text { Mimiaga }\end{array}$ & 2014 & USA & $\begin{array}{l}\text { Transgender and non-transgender sample } \\
\text { Matched on age ( }+/-3 \text { years), } \\
\text { race/ethnicity, educational attainment and } \\
\text { income } \\
\text { Mean age of trans sample }=37.3\end{array}$ & $\begin{array}{l}\text { Matched sub- } \\
\text { sample = } 155 \\
\text { Trans }=31\end{array}$ & $\begin{array}{l}\text { Lifetime suicide attempt and ideation in } \\
\text { trans }>\text { than Cisgender }\end{array}$ \\
\hline Jones et al. & 2015 & Australia & Transgender - MF only & 273 & $\begin{array}{l}\text { Suicidal ideation prevalence rate }=81 \% \\
\text { Suicide attempt prevalence rate }=\text { more } \\
\text { than a third for TF pop. }\end{array}$ \\
\hline
\end{tabular}




\begin{tabular}{|l|l|l|l|l|l|}
\hline Spittal et al. & 2015 & Australia & Callers of a crisis helpline & $\begin{array}{l}411,725 \text { callers, } \\
2594=\text { frequent } \\
\text { callers }\end{array}$ & $\begin{array}{l}\text { Found that a predictor of ringing crisis } \\
\text { helplines is being trans (0.3\% of frequent } \\
\text { callers) }\end{array}$ \\
\hline Reisner et al. & 2015 & USA & $\begin{array}{l}\text { Trans patients aged 12-29 at a Boston } \\
\text { community health centre } \\
\text { Matched on gender identity, age, visit } \\
\text { date, and race/ethnicity to } \\
\text { cisgendergender controls }\end{array}$ & $\begin{array}{l}180 \\
\text { TF }=74(41.1 \%) \\
\text { TM = 106 (58.9\%) }\end{array}$ & $\begin{array}{l}\text { Transgender youth had a twofold to } \\
\text { threefold increased risk of suicidal } \\
\text { ideation, suicide attempt and self-harm } \\
\text { without lethal intent } \\
\text { No significant difference between TF and } \\
\text { TM }\end{array}$ \\
\hline $\begin{array}{l}\text { Birkett, } \\
\text { Newcomb \& } \\
\text { Mustanski }\end{array}$ & 2015 & USA & LGBTQ Youth over 3.5 year period & $\begin{array}{l}231 \\
\text { Trans }=22(9.5 \%)\end{array}$ & $\begin{array}{l}\text { Vulnerability factors for psychological } \\
\text { distress in trans = victimisation }\end{array}$ \\
\hline
\end{tabular}

TF: Trans female; TM: Transmale; NSSI: Non Suicidal Self-Injury; SMRs: Standard Mortality rate due to Suicide 